\title{
Organizacja wiedzy w umyśle człowieka w świetle teorii schematów i gatunków
}

\author{
Marek Nahotko \\ Instytut Informacji Naukowej i Bibliotekoznawstwa \\ Uniwersytet Jagielloński
}

\begin{abstract}
Abstrakt
Cel/teza: Celem artykułu jest przedstawienie poglądów na wiedzę jako rezultatu funkcjonowania ludzkiego umysłu, oraz opis zasad i narzędzi organizacji wiedzy w umyśle człowieka, wykorzystywanych do komunikowania wiedzy, m.in. w postaci zapisów informacji (w przypadku wiedzy naukowej - publikacji naukowych). W tym sensie organizacja wiedzy następuje podczas procesów konwersji wiedzy w informację (nadawca) i informacji w wiedzę (odbiorca).

Koncepcja/metody badań: Na podstawie krytycznej analizy piśmiennictwa z zakresu neurologii, psychologii i socjologii, a także językoznawstwa, dokonano opisu procesów mentalnych realizowanych podczas aktywności twórczej, w szczególności związanej z procesami pisania/czytania publikacji naukowych. Uwzględnione zostały w szczególności teorie genploracji, schematów mentalnych i gatunków. Procesy te i aktywności uznane zostały za procesy organizacji wiedzy.

Wyniki i wnioski: W wyniku realizacji mentalnych procesów organizacji wiedzy, w mózgu człowieka, podczas jego neuronalnej aktywności, powstają umysłowe struktury wiedzy, nazywane różnie (schematy, skrypty, ramy, plany) w zależności od teorii opisującej te zjawiska. Podczas aktywności związanych z komunikowaniem się, struktury te są z kolei podstawą tworzenia konwencji dotyczących formy i treści przekazywanych informacji w formie tekstowej, zwanych gatunkami. Gatunki, jako konwencje znane i stosowane zarówno przez nadawców, jak i odbiorców komunikatów, ułatwiają konwersje typu informacja-wiedza-informacja (twórczość) i wiedza-informacja-wiedza (komunikacja). Oryginalność/wartość poznawcza: Artykuł porządkuje wiedzę o procesach organizacji wiedzy łącząc kilka teorii znanych z neurologii, psychologii i socjologii, co ułatwia właściwe umiejscowienie procesów organizacji wiedzy i stosowanych w niej narzędzi - systemów organizacji wiedzy.
\end{abstract}

\section{Słowa kluczowe}

Gatunki. Genploracja. Organizacja wiedzy. Schematy mentalne. Systemy organizacji wiedzy. Wiedza.

Otrzymany: 12.04.2014. Poprawiony: 14.05.2014. Zaakceptowany: 16.05.2014.

\section{Wprowadzenie}

Według poglądów konstruktywistycznych, autor - tworząc tekst, w jego zamyśle mający być rozpowszechniany jako publikacja - nawiązuje relację ze swoim odbiorcą-czytelnikiem, budując narrację w taki sposób, aby najpełniej osiągnąć zakładane przez siebie cele, na przykład satysfakcjonujący poziom cytowań (Livnat, 2012, 47). Autor, konwertując swoją wiedzę w informacje zawarte w komunikacie (zwykle w tekście), konstruuje treści, których znaczenia są interpretowane przez odbiorcę (czytelnika) i przetwarzane na jego wiedzę. Na tym polega ułomność wszelkiej komunikacji międzyludzkiej, nie tylko naukowej - komunikować możemy się ze sobą tylko za pomocą informacji, dokonując stałych i licznych, wymagających ciągłych 
interpretacji, konwersji między wiedzą i informacją (Talja et al., 1999, 755). Interpretacja informacji odbywa się więc przy udziale wiedzy obu stron procesu komunikacji. Autor konwertuje wybraną część swojej wiedzy w informacje, które następnie interpretowane są przy udziale wiedzy czytelnika. Interpretacje te częściowo związane są z odkrywaniem znaczeń i intencji, ale obejmują także ocenę i wartościowanie. Czasem są oczywiste i niemal automatyczne, w innych przypadkach niedostępne dla określonych interpretatorów (Fairclough, 2003, 11). Ponieważ wiedza autora i odbiorcy są zawsze różne, tak jak różne są ich doświadczenia (choć jednocześnie podobne, do czego przyczynia się np. system powszechnej edukacji), ich interpretacje również zawsze są odmienne. Znaczenie informacji (właściwa interpretacja) jest negocjowane między autorem a czytelnikiem w procesach komunikacji, także naukowej, w trakcie której dochodzi do zbliżenia interpretacji i osiągnięcia dynamicznego konsensusu.

Bożenna Bojar twierdzi, że przyswojenie informacji zawartej w komunikacie powoduje zmianę stanu wiedzy odbiorcy (najczęściej przyrost) proporcjonalny do nowości informacji w stosunku do wiedzy odbiorcy (Bojar, 2013, 20). Nowa informacja, po zinterpretowaniu przez odbiorcę, konwertowana jest w jego wiedzę i wpisywana w odpowiednie struktury wiedzy. W procesie tym uczestniczy nie tylko wcześniej uzyskana wiedza czytelnika oraz informacje przekazane w tekście głównym przez autora, ale także odautorskie informacje uzupełniające i metatekst, zawierający informacje dotyczące formy, struktury, treści, zawartości, relewantności i prawdziwości tekstu, umiejscawiające go w odpowiednim gatunku. Dodatkowo, każdy tekst połączony jest z innymi tekstami relacjami intertekstualnymi, wyrażonymi mniej lub bardziej jawnie, ustanawianymi zarówno przez autora (podczas tworzenia), jak i odbiorcę (podczas interpretacji).

W informatologii szczególną uwagę poświęcano zawsze odbiorcy informacji - użytkownikowi (czytelnikowi), gdyż to jego bezpośrednią obsługą zajmują się pracownicy bibliotek i ośrodków informacji. Stąd też wiele działań praktycznych i refleksji teoretycznej dotyczy sposobów organizacji informacji ${ }^{1}$ zawartych w publikowanych tekstach, reprezentujących wiedzę autorów. Dostęp do tej informacji możliwy jest za pośrednictwem zasobów metainformacji, a te z kolei powstają z udziałem wiedzy osób indeksujących, z wykorzystaniem systemów organizacji informacji, tworzonych zwykle przez jeszcze inne osoby, posiadające własne zasoby i struktury wiedzy. Negocjacje, służące uzgodnieniu interpretacji informacji, są więc tu wielopłaszczyznowe, co jest powodem licznych perturbacji. Wiele uwagi poświęcono stanom wiedzy użytkowników, budując modele zachowań informacyjnych (Mierzecka-Szczepańska, 2013, 56 i nast.), czyli takich, które prowadzą do przyswajania odnalezionej informacji i zapisania jej w strukturach kognitywnych w postaci wiedzy.

W dalszej części artykułu chciałbym zająć się tym elementem procesu komunikacji, który $\mathrm{w}$ informatologii jest rzadziej badany, mianowicie autorem i realizowanymi przez niego procesami twórczymi, wykonywanymi zawsze w kontekście społecznym, czyli konwersją wiedzy w informację za pomocą struktur pełniących rolę systemów organizacji wiedzy. Zanim jednak przejdę do tego zagadnienia, przydatna będzie prezentacja zjawisk zachodzących na poziomie indywidualnym, procesów neurologicznych oraz teorii psychologicznych, wyjaśniających funkcjonowanie struktur wiedzy w umyśle, zarówno autora, jak i czytelnika.

1 Należy zaznaczyć, że wyrażenia stosowane w prezentowanym tekście, takie jak „organizacja informacji”, „organizacja wiedzy”, „system organizacji wiedzy” nie odnoszą się bezpośrednio do denotatów analogicznych pojęć stosowanych w informatologii. Znaczenie tych terminów w informatologii kompetentnie omówiła Jadwiga Woźniak-Kasperek (Woźniak-Kasperek, 2011, 53 i nast.). 


\section{Neurologiczne aspekty twórczości}

Zainteresowanie mechanizmami mózgowymi, stanowiącymi podstawę twórczego myślenia, definiowanego jako proces prowadzący do powstania nowego wytworu, który jest akceptowany jako użyteczny lub do przyjęcia dla określonej grupy w danym czasie (Nęcka, 2012, 18), datuje się przynajmniej od lat 40. XX w. (Abraham, 2014). Początkowo stosowano dość jednolite podejście do funkcji mózgu w działaniu twórczym, które traktowane było jako niezróżnicowany ogólny konstrukt, co dawało korzyści w postaci możliwości tworzenia ogólnych, całościowych teorii. W ten sposób stwierdzono na przykład związek czynności twórczych z funkcjami płata czołowego i wyższą aktywnością prawej półkuli mózgu. Jest to jednak podejście zbyt ogólne dla potrzeb badania neuronalnych mechanizmów przetwarzania informacji służących działaniom twórczym, dlatego cytowana Anna Abraham proponuje podejście procesowe, w którym uwzględniać trzeba wiele działań poznawczych, realizowanych w sposób jednolity.

Podejście to doprowadziło do powstania modelu genploracji, w którym opisywany jest szereg działań umysłowych, realizowanych podczas myślenia twórczego (Ward et al., 1999, 191). W modelu tym wskazuje się na ważną rolę dwóch etapów procesu twórczego: wytwórczego (ang. generative) i interpretacyjnego (ang. exploratory) (Smith et al., 1993, 837). W pierwszej fazie, podczas której powstają wstępne idee i pomysły, mają miejsce takie procesy, jak przywoływanie z pamięci, poszukiwanie analogii i transformacje umysłowe. W ich wyniku tworzone są idee potencjalne, czyli struktury „przedtwórcze”, które w drugiej fazie podlegają ekstensywnej eksploracji i interpretacji (np. badanie ograniczeń konceptualnych), w celu dopasowania pierwotnie ukształtowanych idei do konkretnych celów i warunków. Zgodnie z tym modelem, różnica pomiędzy poznaniem kreatywnym a tym, które potocznie uznawane jest za nietwórcze, czyli normatywnym, nie polega na wykonywaniu odmiennych czynności umysłowych, ale na innym kontekście przetwarzania informacji. Kontekst, czyli sytuacja pobudzająca do rozwiązywania problemu twórczego, jest bardziej otwarty, wieloznaczny, nieliniowy, abstrakcyjny i nieprzewidywalny w stosunku do sytuacji wymaganej dla poznania normatywnego. Wynika z tego, że poznanie twórcze może być uzyskane przez realizację normatywnych procesów poznawczych, ale w warunkach wysoce generatywnych, niejako wymuszających aktywność twórczą. Odpowiednie dla tych warunków działania umysłowe obejmują zdolność do:

- poszerzania ram istniejących struktur konceptualnych (rozszerzenie konceptualne),

- umysłowej wizualizacji podczas tworzenia twórczych idei (twórcze obrazowanie),

- przekraczania ograniczającego wpływu bieżąco aktywowanej wiedzy² (przekraczanie ograniczeń wiedzy),

- nagłego pojawiania się rozwiązań w trakcie rozwiązywania problemów w wyniku zmiany perspektywy badawczej (wgląd ${ }^{3}$ ) (Abraham \& Windmann, 2007, 39).

Pewne struktury mózgu (dolna czołowa, płat skroniowy, płat czołowy) są mocniej uruchamiane podczas kreatywnego rozszerzenia konceptualnego, niż normatywnego

${ }^{2}$ Ograniczenia te polegają na blokowaniu, podczas procesów twórczych, tworzenia nowych idei przez pomysły standardowych rozwiązań problemu, nasuwające się jako pierwsze [Smith et al., 1993, 837).

3 Wgląd definiowany jest też po prostu jako nagła zmiana percepcji problemu (Nęcka, 2012, 104). 
przetwarzania informacji semantycznej (Abraham, 2014, 3).

Podjęcie wysiłku służącego zrozumieniu nowej idei zawsze powoduje tworzenie nowych lub rozbudowę istniejących struktur konceptualnych, skutkujące wprowadzeniem nowych cech lub powiązań. Sieć przetwarzania semantycznego mózgu, gdy zaangażowana jest w rozszerzenie konceptualne, pracuje bardzo intensywnie, szczególnie w swoich wyżej zorganizowanych obszarach, które pośredniczą w selekcji leksykalnej, kontrolowanym wydobywaniu z pamięci i procesach integracji informacji. Ludzki system poznawczy stale stara się stosować posiadaną wiedzę („standardową”) do nowej informacji. Podczas procesu refleksji konieczne jest więc uwolnienie umysłu z ograniczającego wpływu wiedzy „standardowej”. Wcześniej pozyskana informacja zakłócająca, lecz jednocześnie istotna i relewantna, zagraża dalszemu postępowi czynności twórczych przez ograniczanie możliwości tworzenia oryginalnych idei. Tym samym sieć sterowania poznaniem mózgu stara się usunąć te zakłócenia z umysłu. Można tego dokonać na dwa sposoby - przez powstrzymywanie lub ignorowanie pierwotnie pozyskanej relewantnej informacji. Obie te czynności bardzo trudno jest realizować, gdyż mózg cechuje się szczególną biegłością w efektywnych działaniach celowych. Podczas standardowej, codziennej aktywności umysł ludzki funkcjonuje w kontekście normatywnym, gdzie zakłócenia, które trzeba przezwyciężać, mogą być bezbłędnie rozpoznawane i nie są istotne lub relewantne do bieżących zadań. Są one więc łatwo ignorowane. Jednak podczas tworzenia kreatywnych idei, informacja zakłócająca może być nadzwyczaj pertynentna do zadania, więc nie może być potraktowana w podobny sposób. W takich warunkach nierównowagi w układzie czołowo-prążkowym mózgu powstają szczególnie korzystne warunki do twórczego poznania, zapewne dzięki brakowi kognitywnych zahamowań oraz wzrostowi abstrahowania, co ułatwia ignorowanie istotnych czynników rozpraszających (Abraham, 2014, 4).

Neurolodzy, badając funkcje mózgu, poszukują w nim obszarów odpowiedzialnych za twórcze zachowania (Jung et al., 2013, 8). Między innymi głoszone są poglądy, że twórczość nie jest związana z żadnym konkretnym obszarem mózgu, może z wyjątkiem kory przedczołowej, gdzie wykonywanie zadań związanych z twórczym poznaniem zawsze powoduje zmiany (Dietrich \& Kanso, 2010, 845), co potwierdza teorię genploracji. Jest to o tyle prawdopodobne, że mózg nie wykonuje funkcji poznawczych poprzez działania neuronowo-aksonalne w dyskretnych obszarach, płatach, a nawet półkulach. Działa on raczej jak sieć lub zbiór powiązanych obiektów. Mózg jest zorganizowany w sposób, który pozwala na optymalizację przetwarzania różnych rodzajów informacji (np. wizualna - płat potyliczny, audialna - płat skroniowy, sensoryczna - płat ciemieniowy), wraz z korowym łączeniem informacji sensorycznej pochodzącej z wielu źródeł. Okazało się także, że niewiele obszarów w mózgu, zwanych hubami, posiadając nieproporcjonalnie wiele powiązań z innymi obszarami mózgu, służy usprawnieniu połączeń mózgowych poprzez przekazywanie informacji pomiędzy odległymi obszarami mózgu. Uczestniczą one w procesach myślenia niezależnego od stymulacji zewnętrznej. Myślenie takie, nie związane z wykonywaniem konkretnych zadań, ma istotne znaczenie dla procesów wnioskowania i poznania, czyli m.in.: zapamiętywania przeszłości, przewidywania przyszłości, uwzględniania poglądów i punktów widzenia innych ludzi. Zapewne obszary te odgrywają istotną rolę podczas twórczego poznania. Kluczem do twórczości może być więc nie tyle aktywność określonych obszarów mózgu, co sprawność przepływu informacji pomiędzy nimi (Jung et al., 2010, 406). 


\section{Umysłowe reprezentacje wiedzy}

Psychologia jest dziedziną, w której prowadzi się badania nad procesami myślowymi realizowanymi indywidualnie. Opierają się one na wynikach badań neurologicznych, ale dotyczą wyższego poziomu struktur umysłowych. Z punktu widzenia problemów przedstawianych w artykule, szczególnie interesujące są badania reprezentacji struktur tekstu, powstających w umyśle czytelnika, które wskazują na sposoby tworzenia tych reprezentacji, zróżnicowanie ich form i wpływ na aktywność użytkownika w obszarze przetwarzania informacji.

Od ponad 20 lat bardzo silnie oddziałuje na te badania teoria schematów poznawczych. Schematy uważane są za abstrakcyjne struktury wiedzy (Pearson, 2009), dobrze zintegrowane fragmenty sieci semantycznej ${ }^{4}$, służące reprezentacji pojęć przechowywanych w pamięci (Rumelhart \& Ortony, 1977). Koncepcja ta wykorzystywana była przez wielu autorów, którzy stosowali własną terminologię do określenia wiedzy abstrakcyjnej i struktur pamięci, pisząc o ramach (Minsky, 1975), skryptach lub planach (Schank, 1999, 107) oraz makrostrukturach (Dijk \& Kintsch, 1983, 189). Mimo tej różnorodności najczęściej używa się terminów schemat (ang. schema) i schematy (ang. schemata), zazwyczaj z myślą o wszystkich odmianach tej teorii.

Według teorii schematów poznawczych pojęcia, obiekty, sytuacje, wydarzenia, działania i ich sekwencje nie są przechowywane w pamięci w sposób nieuporządkowany, lecz tworzą schematy. Te ostatnie są więc w pewnym sensie stereotypami pojęć. Jak twierdzą David Rumelhart i Andrew Ortony, schematy posiadają następujące cechy, pozwalające im funkcjonować jako reprezentacje wiedzy w pamięci:

- Schematy zawierają miejsca przeznaczone na zmienne. Miejsca w schemacie mogą być wypełniane konkretnymi zmiennymi, w zależności od potrzeby. Na przykład w schemacie daru mogą znajdować się zmienne: darczyńca, dar i otrzymujący, w miejsce których umieszcza się konkretne wartości, w zależności od sytuacji.

- Schematy mogą się w sobie zawierać (zagnieżdżać), tworząc relacje.

- Schematy zawierają pojęcia różniące się poziomem abstrakcji, od podstawowych elementów konceptualnych, takich jak konfiguracja linii tworzących kwadrat, po abstrakcyjne poziomy konceptualne pozwalające na tworzenie poprawnych powiązań sekwencji wydarzeń występujących w znacznych okresach.

- Schematy reprezentują raczej wiedzę niż definicje. Są więc bardziej czymś w rodzaju encyklopedii niż słowników (Rumelhart \& Ortony, 1977, 101).

Teoria schematu, rozumiana tak, jak przedstawili ją wymienieni autorzy, jest teorią struktury ludzkiej wiedzy, w szczególności jej reprezentacji w pamięci. Według niej możemy wyobrażać sobie schematy jako małe pojemniki, w których deponowane są ślady codziennie zdobywanych doświadczeń oraz myśli i idee, które wyprowadzane są z tych doświadczeń. Jako przykład często podaje się „schemat krzesła”, który uzupełniany jest o doświadczenie wizualne, gdy widzimy konkretny egzemplarz krzesła. Natomiast wyjście do restauracji ${ }^{5}$ powoduje wywołanie i ewentualne uzupełnienie „schematu restauracji”, który może składać

${ }^{4}$ Reprezentacje pojęciowe w systemie poznawczym są powiązane złożonymi relacjami opisanymi w modelu sieci semantycznej (Nęcka et al., 2012, 126). Pojęcia są przechowywane w pamięci w postaci struktury sieciowej, w której węzłach kodowane są reprezentacje pojęciowe, łączone relacjami.

${ }^{5}$ Jest to ulubiony przykład złożonych struktur poznawczych, wykorzystywany przez Rogera Schanka, który zajmował się głównie stereotypizacją zachowań społecznych, w odróżnieniu od Rumelharta i Ortony, którzy bliżsi byli koncepcjom poznawczego reprezentowania obiektów rzeczywistych w umyśle człowieka. 
się z tzw. subschematów rezerwacji, zajmowania stolika, zamawiania, płacenia itp. Struktura schematów jest więc hierarchiczna. Schematy różnią się poziomem szczegółowości, reprezentując wiedzę ze wszystkich poziomów, od pojedynczych reprezentacji pojęciowych do rozbudowanych ideologii, co jednocześnie powoduje zróżnicowanie zakresu stosowalności schematów (Nęcka et al., 2012, 129). Takie podejście ujmuje w ramy obszernej i szczegółowej teorii to, co jest zwykle intuicyjne postrzegane, mianowicie fakt, że człowiek (i zapewne nie tylko) rozumie i uczy się rzeczy nowych w oparciu o to, czego wcześniej się nauczył. Wyjaśnia to też codzienne zjawisko odmiennego interpretowania tych samych wydarzeń oraz tekstów - brak idealnego porozumienia wynika z różnic w dotychczas zdobytych doświadczeniach i związanej z nimi, nagromadzonej wiedzy (a więc i schematów poznawczych).

Teoria schematów wykorzystywana jest w badaniu różnych zjawisk, także w badaniach nad odbiorem tekstu, które skoncentrowane są na dwóch problemach - konstruktywistycznej naturze zrozumienia oraz zasadniczej rolą wiedzy posiadanej przez czytelnika dla konstruowania rozumienia tekstu (Sadoski et al., 1991, 465). Jak twierdzą Richard Anderson i David Pearson, teoria schematów spowodowała zmianę myślenia o takich problemach, jak sposoby asymilacji informacji znajdujących się w komunikacie tekstowym, jej interpretacji, wyciągania wniosków, zapamiętywania tekstu, czyli jego rozumienie (Anderson \& Pearson, 1984, 2).

Podstawą stosowania schematów w badaniach nad procesem czytania jest traktowanie czytelnika jako aktywnego konstruktora znaczenia, czynnie posługującego się językiem i informacją, który filtruje zasoby czytelnicze (komunikaty przedstawione przez autora w tekście) za pomocą zasobu własnej wiedzy, aby w sposób ciągły korygować dynamiczny, bieżąco kształtowany model eksploracji tekstu. W taki sposób podkreślamy rolę czytelnika, stawiając go ponad tekstem, tak jak budowniczy ważniejszy jest od materiałów budowlanych, których używa.

Według Richarda Andersona schematy mogą być wykorzystywane podczas czytania tekstów w następujący sposób:

- Stanowią wyidealizowaną strukturę stosowaną do asymilacji informacji z tekstu. Posiadają one przestrzenie, które zapełniane są informacjami z tekstu. Informacje wypełniające te przestrzenie są łatwo przyswajane i zapamiętywane.

- Umożliwiają czytelnikowi określenie istotnych cech tekstu. Dzięki temu, że czytelnik wie, co jest ważne, może łatwiej decydować, na których miejscach w tekście należy skupić uwagę.

- Pozwalają na wnioskowanie, niezbędne ze względu na to, że żaden tekst nie jest do końca jednoznacznie (explicite) sprecyzowany znaczeniowo.

- Pozwalają czytelnikowi na lepsze wykorzystanie pamięci do gromadzenia informacji uzyskanych z tekstu, a także na systematyczne przeszukiwanie pamięci.

- Zawierają ważne kryteria, pozwalające czytelnikowi na edycję i streszczanie ważnych obszarów tekstu oraz na minimalizację roli informacji nieistotnej.

- Wspierają pamięć przez umożliwienie czytelnikowi łatwiejszej rekonstrukcji zagubionej lub zapomnianej partii informacji tekstowej (Anderson, 1984, 244).

W procesie interpretacji tekstu stosowane są dwa rodzaje schematów (Anderson et al., 1979, 2). Pierwszy z nich zawiera wiedzę o konwencjach dyskursu, sygnalizując organizację tekstu. Istnieją specjalne konwencje, charakterystyczne dla poszczególnych form tekstu, a także wspólne dla większości z nich; można więc mówić o schemacie opowieści, 
schemacie listu, schemacie artykułu prasowego, schemacie raportu z badań naukowych (w określonej dziedzinie), artykułu naukowego i wielu podobnych. Takie schematy, zawierające wiedzę o konwencjach na poziomie dyskursu, mogą być łącznie nazywane schematami tekstowymi.

Schematy innego rodzaju, nazywane schematami treści, zawierają wiedzę czytelnika o świecie rzeczywistym i wyimaginowanym. Posiadane przez czytelnika schematy istotnie wspomagają budowę kolejnych struktur dla interpretacji nowych informacji w tym zakresie. Według cytowanych autorów, dla rozumienia czytanego tekstu schematy treści są ważniejsze od schematów tekstowych. Z badań nad schematami treści wynikają dwa wnioski. Po pierwsze, czytelnicy wnioskują zgodnie z posiadanymi przez nich schematami. Po drugie, zwracają większą uwagę na informacje tekstowe, ważne z punktu widzenia stosowania swoich schematów. Istnieją dwa wytłumaczenia tych zjawisk. Hipoteza dotycząca kodowania wskazuje na procesy aktywne podczas czytania. Hipotezy wyszukiwawcze mówią o procesach aktywnych po czytaniu, gdy informacja jest zapamiętywana. Ci, którzy skłaniają się w stronę kodowania uważają, że schemat czytelnika zarządza lokowaniem uwagi na istotnych aspektach tekstu, tworzy ogólne rusztowanie, wypełniane otrzymywaną informacją i/lub umożliwia wnioskowanie w miejscach, gdzie tekst jest niejasny. W późniejszym czasie, gdy tekst jest przywoływany z pamięci, schemat operacyjny stanowi strukturę, która umożliwia uporządkowane przeszukiwanie pamięci, dostarczając kryteriów selekcji informacji nieważnej lub niepewnej i/lub umożliwia na podstawie wnioskowania rekonstrukcję miejsc, w których powstały luki w pamięci. Schematy wpływają zarówno na stan pamięci, jak i na proces uczenia się.

W wyniku takiego stosowania schematów pewne nieistniejące w tekście treści mogą być uzupełniane przez czytelnika, na podstawie posiadanych przez niego schematów. Gdy na przykład czytamy o wypadku samochodowym, możemy uzupełnić obraz przedstawiony w tekście dodatkowymi elementami, których w nim nie było, np. rozbitym szkłem, jeśli z doświadczenia czytelnika wynika, że podczas wypadków samochodowych pojawia się dużo stłuczonego szkła. Później, gdy tekst jest przywoływany z pamięci, trudno jest odróżnić elementy treści dostarczone przez autora (z jego schematu), od dodanych przez własny schemat (jak rozbite szkło z przykładu).

Badania umysłowych struktur reprezentacji tekstu pozwalają wskazać sposoby ich powstawania, formy i przyczyny zróżnicowania oraz wpływ na zachowania czytelnika $\mathrm{w}$ aspekcie przetwarzania informacji. W tym zakresie często przywoływany jest model strategicznego przetwarzania dyskursu Waltera Kintscha i Teuena Van Dijk (Dijk \& Kintsch, 1983, 10). Był on kilkakrotnie modyfikowany i uszczegółowiany, również dzięki licznym zastosowaniom w badaniach nad przetwarzaniem tekstu. Wykorzystuje rozwiązania przyjęte w teorii schematów. Początkowo autorzy uważali, że dyskurs jest interpretowany jako zbiór propozycji (tworzonych na podstawie znaczenia słów) i organizowany przez relacje semantyczne między nimi. Powstająca w ten sposób struktura semantyczna jest dzielona na poziomy mikrostruktur i makrostruktur. Oba poziomy strukturalne są wiązane ze sobą przy pomocy zbioru zasad mapowania semantycznego, zwanych makrozasadami, pochodzącymi i używanymi przez schemat ogólny. Model ten zmodyfikowano w kilku miejscach. Wyróżniono trzy poziomy reprezentacji tekstu w pamięci, w tym reprezentację powierzchniową, podstawę propozycyjną (jak w pierwotnej wersji) oraz model sytuacyjny, który czytelnik konstruuje na temat sytuacji denotowanej przez tekst. Jest on kognitywną reprezentacją 
sytuacji, wydarzeń, działań i osób, o których traktuje tekst. Mentalne reprezentacje tekstu nazywane są superstrukturami (Dijk \& Kintsch, 1983, 236). Jest to abstrakcyjny schemat, ustalający globalny porządek tekstu, przez co służy podziałom typologicznym tekstów. Warunkuje on reakcję czytelnika w takim sensie, że ten próbuje tworzyć efektywne hipotezy robocze o superstrukturze i znaczeniu czytanego tekstu. Hipotezy te są potwierdzane (lub nie) podczas dalszego czytania. Rozumienie dyskursu rozpoczyna się od konstruowania bazy tekstowej bezpośrednio z dyskursu. Dzięki pomyślnemu utworzeniu bazy tekstowej, czytelnik jest w stanie zbudować w pamięci wspomniany model sytuacyjny. Baza tekstowa budowana jest również przez zestaw makrostrategii, które zapewniają ogólną koherencję tekstu. Makrostrategie mogą być budowane na kilku poziomach makropropozycji, co w sumie daje jedną, wielką makrostrukturę. Obecność makrostruktur jest bezpośrednio wyrażana w dyskursie w formie nagłówków, tytułów i inicjałów, a także zaimków, spójników, kolejności słów i ogólnej organizacji tekstu, dokonanej przez autora.

Cytowani autorzy stwierdzają, że wiele rodzajów dyskursów może zawierać reprezentacje mentalne wyższego poziomu w formie superstruktur. Dla tych dyskursów, które wykazują dużą regularność, superstruktura organizuje makropropozycje. Czytelnik stosuje strategię przetwarzania schematycznego, gdy natrafia na znajomy dla siebie rodzaj dyskursu.

Teoria schematów funkcjonuje również w dalej idących odmianach, czego przykładem jest teoria podwójnego kodowania (Sadoski et al., 1991, 473). Zakłada się w niej, że poznanie składa się z aktywności dwóch odrębnych systemów mentalnych, z których jeden wyspecjalizowany jest w reprezentacji i przetwarzaniu informacji dotyczącej obiektów i zdarzeń niewerbalnych, a drugi dotyczy obsługi języka. Podsystem niewerbalny (sensoryczny) określa się też mianem systemu przedstawiającego (ang. imagery), gdyż jego funkcją jest analiza scen i tworzenie mentalnych odwzorowań, zarówno wizualnych, jak i w innych modalnościach - słuchowych, dotykowych i afektywnych. Podsystem wyspecjalizowany w języku określany jest jako system werbalny. Systemy te są odrębne, ale ze sobą powiązane. Mogą funkcjonować oddzielnie, równolegle lub w sposób zintegrowany. Informacja w systemie werbalnym jest organizowana w sposób sprzyjający przetwarzaniu sekwencyjnemu, syntaktycznemu. Informacja niewerbalna (w szczególności wizualna) jest organizowana $\mathrm{w}$ formie holistycznych zagnieżdżonych zestawów $\mathrm{z}$ informacją dostępną do przetwarzania w sposób synchroniczny i równoległy.

\section{Socjologiczna teoria gatunków}

Odpowiednikiem indywidualnych struktur umysłowych - różnych, ale zbudowanych na tych samych zasadach - na poziomie komunikacji tekstowej są gatunki (ang. genres). Ludzki umysł, zarówno porządkuje wiedzę w schematy dotyczące sekwencji wydarzeń, mających miejsce w rutynowych sytuacjach, jak również gromadzi schematy dla strukturalnej lub retorycznej organizacji komunikatów. Schematy te ułatwiają autorowi organizację jego wiedzy w postaci komunikatu zawierającego informacje, a użytkownikowi konstruowanie hipotez i potwierdzanie założeń dotyczących czytanego tekstu. Czytelnik, który poznał strukturę retoryczną zastosowaną przez autora działa efektywniej, niż ten, który tej struktury nie „dostrzega” (Meurer, 1991, 174). Zakres tekstów, w których interpretacji użytkownik może partycypować, zależy więc od liczby schematów, które potrafi poprawnie stosować. 
Dla ułatwienia, a czasem umożliwienia procesu komunikacji, przekazywana informacja musi podlegać określonym konwencjom dotyczącym jej formy i treści (Montesi \& Owen, 2008, 146). Konwencje te nazywane są gatunkami i traktowane jako wzorzec organizacji tekstu (Gajda, 1993, 255). Autor tekstu, tworząc komunikat, posługuje się konwencjonalnymi strukturami (gatunkami), pozwalającymi na sprawną konwersję wiedzy w informację, czyli na organizację wiedzy. Jednocześnie to samo narzędzie ułatwia konwersję informacji w wiedzę odbiorcy, czyli organizację jego wiedzy ${ }^{6}$. Konwersja schematów umysłowych na odpowiednie gatunki tekstu jest wynikiem analizy strukturalnej komunikowanej informacji, dokonywanej przez autora (Hyland, 1990, 67). Dodatkowo z badań wynika, że z punktu widzenia odbiorcy, strukturalne cechy komunikatu tekstowego zawierającego informacje są ściśle związane z cechami konceptualnymi, a interpretacja informacji odbywa się na zasadach, które są bardziej złożone niż gdyby dotyczyły jedynie fizycznej organizacji. Zaawansowani czytelnicy stosują te zasady niemal automatycznie (Dillon \& Vaughan, 1997, 97), stanowią więc one składnik kompetencji komunikacyjnej.

Podczas budowania znaczeń w relacjach społecznych, którego częścią może być tworzenie tekstów, ludzie tworzą tekstowe reprezentacje różnych aspektów świata (fizycznego, społecznego i umysłowego) oraz budują relacje społeczne pomiędzy uczestnikami wydarzeń w oparciu o postawy, pragnienia i wartości wyznawane przez uczestników. Znaczenia te funkcjonują w trzech aspektach: gatunków (sposoby działania), dyskursów (sposoby reprezentacji) i stylów (sposoby istnienia). Gatunki wyrażają dyskursywny aspekt stosowanych sposobów działania i interakcji w trakcie aktywności społecznych. Jak twierdzi Norman Fairclough, interakcje te w głównej mierze mają charakter dyskursywny (Fairclough, 2003, 65). Podczas analizy interakcji zapośredniczonej przez tekst na gruncie teorii gatunków badamy więc umiejscowienie tekstu i jego udział w aktywności społecznej. W szczególności zmiany w interakcjach społecznych wiążą się ze zmianami w stosowaniu gatunków. Z drugiej strony, gatunki, jako forma interakcji, stanowią określony rodzaj relacji społecznych pomiędzy jednostkami (organizacjami, grupami i osobami), pozostającymi w interakcji.

Teoria gatunków jest wykorzystywana w wielu naukach, takich jak kulturoznawstwo, językoznawstwo, retoryka, ekonomia i socjologia. Z tego też powodu powstało wiele definicji gatunku, tworzonych z różnych punktów widzenia. Misha Vaughan i Andrew Dillon zaproponowali definicję kompleksową, uwzględniającą podobieństwa i różnice zawarte we wcześniejszych definicjach. Według nich gatunek jest to klasa wydarzeń komunikacyjnych, które cechują się stosowaniem podobnych konwencji i zasad służących ułatwianiu interakcji poprzez tworzenie i obsługę oczekiwań (przewidywań) w społecznościach twórców i odbiorców (Vaughan \& Dillon, 2006, 503). W nauce, społeczności uczonych wykształciły efektywne retoryczne i specyficzne dla poszczególnych dyscyplin sposoby konstruowania wiarygodnych sprawozdań (relacji) z badań. Stosowane tam gatunki odzwierciedlają zasady prowadzenia badań z uwzględnieniem specyfiki dyscypliny (Montesi \& Owen, 2008, 163).

John Swales, autor jednej z lepiej znanych językoznawczych teorii gatunków, twierdził, że gatunek musi spełniać pięć kryteriów:

(1) Gatunek jest klasą wydarzeń komunikacyjnych.

${ }^{6}$ Pomiędzy procesami organizacji wiedzy nadawcy (autora) i odbiorcy (czytelnika) znajdują się zazwyczaj procesy organizacji informacji, w wyniku których powstaje metainformacja, ułatwiająca odszukanie komunikatu, zawierającego informację relewantną do potrzeb odbiorcy. 
(2) Głównym kryterium, które powoduje zaliczenie zbioru wydarzeń komunikacyjnych do jednego gatunku, jest wspólny zbiór celów komunikacyjnych.

(3) Wystąpienia poszczególnych gatunków mogą się między sobą różnić.

(4) Uzasadnieniem wyodrębnienia gatunku są przyjęte dla niego ograniczenia w zakresie możliwych zastosowań treści i formy.

(5) Nazewnictwo stosowane w obrębie społeczności dyskursu, stosującej dany gatunek jest ważnym źródłem wiedzy o jego zastosowaniach (Swales, 1990, 45-58).

Teoria gatunków opiera się na koncepcji, według której teksty są do siebie mniej lub bardziej podobne, a na podstawie podobieństw mogą być klasyfikowane jako należące do wspólnego gatunku (Hyland \& Salager-Meyer, 2008, 303). Klasyfikowanie to, inaczej niż w klasyfikacji rozumianej jako podział logiczny, wykorzystuje teorię prototypów (dla zobrazowania struktury kategorii), podobieństwa rodzinnego i koncepcję zbiorów rozmytych (dla zobrazowania relacji wewnątrz kategorii i między kategoriami) (Witosz, 2003, 91). Podstawą tego klasyfikowania są cechy językowe i retoryczne, a także strukturalne każdego gatunku. Podobieństwa wynikają więc z cech tekstu, które autor wykorzystuje nie tylko do przedstawienia swojej wizji świata, ale do negocjowania z czytelnikiem wiarygodności własnej i swego dzieła przez nakłanianie odbiorcy do wejścia w bliskie związki z tekstem i jego autorem, wpływanie na ocenę prezentowanych pomysłów i uznawanie alternatywnych poglądów. Tworzone relacje interpersonalne odnoszą się do sposobów stosowania języka przez autora podczas negocjowania relacji społecznych, przez wskazywanie czytelnikowi tego, co autor uważa za istotne, jego poglądów na właściwy sposób selekcji i prezentacji materiału oraz wybór treści (Hyland, 2010, 116). Jak pisze Maria Wojtak, obraz relacji nadawczo-odbiorczych, wykorzystujących konwencje gatunku, wiąże się nie tylko z zamiarem komunikacyjnym nadawcy, ale ma także wymiar poznawczy (Wojtak, 2001, 44). Użycie zasad wybranego gatunku ułatwia te działania na dwa sposoby. Po pierwsze, autor stosuje konwencje obowiązujące w dyscyplinie do budowania swego autorytetu w oczach audytorium kolegów-naukowców. Po drugie, autor umieszcza się we właściwej, we własnym mniemaniu, pozycji w stosunku do prezentowanych materiałów.

Analiza gatunków realizowana jest zgodnie z dwoma podstawowymi założeniami. Po pierwsze, cechy każdej grupy tekstów zależą od społecznego kontekstu ich tworzenia i konsumpcji. Po drugie, cechy te mogą być opisane w sposób wiążący relacjami tekst z innymi, podobnymi do niego, a także z wyborami i ograniczeniami wpływającymi na twórców tekstów. Język jest wówczas postrzegany jako włączony w rzeczywistość społeczną, a zarazem konstytuujący ją, gdyż poprzez bieżące korzystanie ze skonwencjonalizowanych form autorzy i czytelnicy budują relacje tworzące społeczności i osiągają swoje cele. Gatunki są więc wynikiem aktywności pojedynczych członków społeczności posiadających wiedzę przynajmniej dwojakiego rodzaju. Po pierwsze, dotyczy ona ograniczeń związanych z doświadczeniami historycznymi oraz kontekstem, w którym jednostka funkcjonuje współcześnie. Po drugie, posiadają wiedzę o dostępnych rodzajach gatunków. Są one więc semiotyczną stroną wydarzeń społecznych realizowanych są na poziomie tekstowym. Każdy tekst funkcjonuje w obrębie jakiegoś gatunku. Gatunki definiują tekst z punktu widzenia dozwolonych działań, relacji społecznych pomiędzy uczestnikami wydarzenia komunikacyjnego oraz zastosowanego formatu i formy tekstu (Bezemer \& Kress, 2008, 173). Tekst może być więc klasyfikowany do różnych gatunków pod względem różnych rodzajów interakcji, które tworzy z czytelnikami oraz różnych rodzajów perswazji, stosowanych przez autora. 


\section{Podsumowanie}

Wiedza jest wynikiem funkcjonowania umysłu ludzkiego ${ }^{7}$, poza umysłem nie funkcjonuje, przez co nie może być bezpośrednio przekazywana. Aby wiedza była komunikowana, musi być skonwertowana do postaci informacji. W tej postaci może być przechowywana, transmitowana i powtórnie przekształcana w wiedzę odbiorcy. Procesy te odbywają się tak często w codziennym życiu i są tak powszechne, że prawie niedostrzegalne. Nie można wykluczyć zresztą, że nie są one wyłącznie domeną ludzką. Człowiek ma jednak do dyspozycji nadzwyczaj rozbudowane narzędzia organizacji wiedzy i informacji - język i technologie informacyjne wspomagające pamięć i wzmacniające przekaz w czasie i przestrzeni.

Wiedza w procesach umysłowych jest organizowana. Procesy organizacji wiedzy, podobnie jak sama wiedza, mają charakter indywidualny, tak jak indywidualnie gromadzone są doświadczenia. Z drugiej strony osoby żyjące w tym samym czasie, miejscu i kręgu kulturowym mają wspólne doświadczenia, a więc posiadają podobne struktury umysłowe, stanowiące podstawę indywidualnej organizacji wiedzy. Ponadto neuronalne podstawy procesów organizacji wiedzy uwarunkowane są genetycznie, a więc są wspólne dla całego gatunku ludzkiego.

Organizacja wiedzy odbywa się wielopoziomowo. Obejmuje procesy realizowane na poziomie neuronalnym i umysłowym, co zresztą jest cechą charakterystyczną ludzkiego mózgu. Rzadko czynności poznawcze realizowane są w jednym, ściśle określonym obszarze mózgu, zwykle powodują zróżnicowaną aktywność wielu jego obszarów, a sedno aktywności twórczych może tkwić we właściwym przepływie informacji pomiędzy obszarami mózgu (Jung et al., 2010, 405). Poza tym jednak indywidualny umysł ludzki nie funkcjonuje w izolacji od innych, wręcz przeciwnie, jest z nimi połączony stałymi interakcjami, co wymusza potrzebę komunikowania się. Komunikowanie to przyjmuje społecznie negocjowane formy, zwane gatunkami. Andrew Dillon wskazuje na trzy poziomy struktur, służących organizacji wiedzy (Dillon, 2004, 118). Po pierwsze, chodzi o struktury budowane przez czytelnika w celu wydobycia i przetworzenia informacji z dokumentu. Po drugie, mówić można o strukturach reprezentujących konwencje, zasady stosowane przez autora podczas tworzenia dokumentu. I na koniec, struktury mogą być traktowane jako sposób na przekazywanie informacji o kontekście. Jest to wówczas naturalnie występująca struktura związana z dowolnym tematem, która zawiera „podstawowe dane” z określonej dziedziny, wspomagając czytanie. Według Dillona wszystkie trzy zjawiska oznaczają to samo zagadnienie, dla którego używa on terminu 'kształt' (ang. shape), zawierające zarówno elementy dotyczące formy, jak i treści informacji.

Realizacja aktu komunikacji z wykorzystaniem konwencji określonego/określonych gatunku/gatunków powoduje tworzenie informacji, która po utrwaleniu (zmaterializowaniu) także może podlegać procesom organizacji. W tym celu tworzone są systemy organizacji informacji, w czym specjalizują się pracownicy takich instytucji, jak biblioteki. Bibliotekarze organizują i realizują procesy mediacji pomiędzy obiema stronami procesów organizacji wiedzy: nadawcami (twórcami, autorami) i odbiorcami (czytelnikami). Szczególnie

${ }^{7}$ Umysł rozumiany jest tu jako ogół aktywności mózgu. Według psychologów mózg jest materialnym podłożem działania umysłu, jako systemu poznawczego, co oznacza, że funkcje umysłowe zachodzą na materialnym podłożu tkanki nerwowej i w ścisłej zależności od procesów przebiegających w tej tkance (Nęcka et al., 2012, 24). 
interesujące wydają się problemy związane z implementacją nowych, elektronicznych narzędzi, stosowanych w tej mediacji, z których najważniejszym jest Internet. Stwarza on m.in. możliwości komunikacji bez pośrednictwa wspomnianych instytucji (zmienia sposób transferu i organizacji informacji), a także jest środowiskiem powstawania nowych gatunków. Określenia, takie jak „książka elektroniczna” i „czasopismo elektroniczne” to metafory, wskazujące na powstawanie nowych form komunikacji, które z wcześniej istniejącymi łączy tylko wykorzystywanie tekstu jako głównego nośnika informacji (Kotuła, 2013, 111). Nowe, elektroniczne gatunki są przyczyną powstawania odpowiednich dla nich schematów poznawczych.

\section{Bibliografia}

Abraham, A. (2014). Creative thinking as orchestrated by semantic processing vs. cognitive control brain networks. Frontiers in Human Neuroscience [online], 8(95), [20.03.2014], http://journal. frontiersin.org/Journal/10.3389/fnhum.2014.00095/

Abraham, A.; Windmann, S. (2007). Creative cognition: the diverse operations and the prospect of applying a cognitive neuroscience perspective. Methods, 42(1), 38-48.

Anderson, R. (1984). Role of readers' schema in comprehension, learning and memory. In: R. Anderson, J. Osbourne, R. Tierney (eds.) Learning to read in American schools: basal readers and content text. Hillsdale: Erlbaum Assoc., 243-258.

Anderson, R.; Pearson, D. (1984). A schema-theoretic view of basic processes in reading comprehension. Champaign: Univ. of Illinois.

Anderson, R.; Pichert, J.; Shirey, L. (1979). Effects of the reader's schema at different points in time. Technical Report no. 119. Champaign: Univ. of Illinois.

Bezemer, J.; Kress, G. (2008). Writing in multimodal texts. A social semiotic account of designs for learning. Written Communication, 25(2), 166-195.

Bojar, B. (2013). Przestrzeń informacyjna tekstu. Studium jednego przypadku. Zagadnienia Informacji Naukowej, 1(101), 20-36.

Dietrich, A.; Kanso, R. (2010). A review of EEG, ERP and neuroimaging studies of creativity and insight. Psychological Bulletin, 136(5), 822-848.

Dijk, T.; Kintsch, W. (1983). Strategies of discourse comprehension. New York: Academic Press.

Dillon, A. (2004). Designing usable electronic text. Boca Raton; London; New York: CRC Press.

Dillon, A.; Vaughan, M. (1997). It's the journey and the destination: shape and the emergent property of genre in evaluating digital documents. New Review of Multimedia and Hypermedia, 3, 91-106.

Fairclough, N. (2003). Analysing discourse: textual analysis for social research. London; New York: Routlege.

Gajda, S. (1993). Gatunkowe wzorce wypowiedzi. W: J. Bartmiński (red.) Encyklopedia kultury polskiej XX wieku, t. 2, Wspótczesny język polski, Wrocław: Wiedza o Kulturze, 255-268.

Hyland, K. (2010). Constructing proximity: relating to readers in popular and professional science. Journal of English for Academic Purposes, 9(2), 116-127.

Hyland, K. (1990). A genre description of the argumentative essay. RELC Journal, 21(1), 66-78.

Hyland, K.; Salager-Meyer, F. (2008). Scientific writing. Annual Review of Information Science and Technology, 42(1), 297-338.

Jung, R. [et al.] (2013). The structure of creative cognition in the human brain. Frontiers in Human Neuroscience [online], 7 (330), [2.04.2014], http://journal.frontiersin.org/Journal/10.3389/ fnhum.2013.00330/

Jung, R.; Segall, J.; Bockholt, J.; Flores, R.; Smith, S.; Chavez, R.; Haier, R. (2010). Neuroanatomy of creativity. Human Brain Mapping, 31(3), 398-409. 
Kotuła, S. (2013). Komunikacja bibliologiczna wobec World Wide Web. Lublin: Wydaw. UMCS. Livnat, Z. (2012). Dialogue, science and academic writing. Amsterdam: John Benjamins Publ. Meurer, J. (1991). Schemata and reading comprehension. Ilha do Desterro, 25/26, 167-184.

Mierzecka-Szczepańska, A. (2013). Badania zachowań informacyjnych. Warszawa: Wydaw. SBP.

Minsky, M. (1975). A framework for representing knowledge. In: P. Wilson (ed.) The psychology of computer vision. New York: McGraw-Hill, 211-277.

Montesi, M.; Mackenzie Owen, J. (2008). Research journal articles as document genres: exploring their role in knowledge organization. Journal of Documentation, 64(1), 143-167.

Nęcka, E. (2012). Psychologia twórczości. Sopot: Gdańskie Wydaw. Psychologiczne.

Nęcka, E.; Orzechowski, J.; Szymura, B. (2012). Psychologia poznawcza. Warszawa: Wydaw. Naukowe PWN.

Pearson, D. (2009). The roots of reading comprehension instruction. In: S. Israel \& G. Duffy (eds.) Handbook of research on reading comprehension. New York: Routledge, 3-31.

Rumelhart, D.; Ortony, A. (1977). The representation of knowledge in memory. In: R. Anderson, R. Spiro, W. Montague (eds.) Schooling and the acquisition of knowledge. Hillsdale: Erlbaum, 99-135.

Sadoski, M.; Paivio, A.; Goetz, E. (1991). A critique of schema theory in reading and dual coding alternative. Reading Research Quarterly, 26(4), 463-484.

Schank, R. (1999). Dynamic memory revisited. Cambridge: Cambridge Univ. Press.

Smith, S.; Ward, T.; Schumacher, J. (1993). Constraining effects of examples in a creative generation tasks. Memory \& Cognition, 21(6), 837-845.

Swales, J. (1990). Genre analysis : English in academic and research settings. Cambridge: Cambridge Univ. Press.

Talja, S.; Keso, H.; Pietiläinen, T. (1999). The production of 'context' in information seeking research: a metatheoretical view. Information Processing $\mathcal{E}$ Management, 35(6), 751-763.

Vaughan, M.; Dillon, A. (2006). Why structure and genre matter for users of digital information: a longitudinal experiment with readers of a web-based newspaper. International Journal of Human-Computer Studies, 64(6), 502-526.

Ward, T.; Smith, S.; Finke, R. (1999). Creative cognition. In: R. Sternberg (ed.) Handbook of creativity. Cambridge: Cambridge Univ. Press, 189-212.

Witosz, B. (2003). Schematy, wzorce tekstowe, gatunki mowy... (O kategoryzacji, kategoriach wypowiedzi językowych i ich modelowaniu). Przestrzenie Teorii, 2, 89-102.

Wojtak, M. (2001). Pragmatyczne aspekty analiz stylistycznych tekstów użytkowych. W: B. Witosz (red.) Stylistyka a pragmatyka. Katowice: Wydaw. Uniw. Śląskiego, 38-47.

Woźniak-Kasperek, J. (2011). Wiedza i język informacyjny w paradygmacie sieciowym. Warszawa: Wydaw. SBP.

\title{
Organization of Knowledge in Human Mind in the Light of Schemata and Genres Theory
}

\begin{abstract}
Purpose/thesis: The purpose of the paper is to present concepts of knowledge understood as a result of the activity of human mind and describe the framework for knowledge organization in the human mind, which is being used to communicate knowledge as recorded information (in the case of scientific knowledge these records are scientific publications). In this sense, the organization of knowledge takes place when knowledge is processed into information (sender side) and converted from the information back to the knowledge (recipient side).
\end{abstract}


Approach/method: Based on a critical analysis of the literature in the field of neuroscience, psychology, sociology and linguistics, the author introduces the description of mental processes related to creative activities, in particular those related to the processes of writing and reading scientific publications. Theories of genploration, mental schemata and text genres are taken into consideration. Processes and activities in question have been recognized as the processes of knowledge organization. Results and conclusions: Mental knowledge structures are being formed as a result of the mental processes of knowledge organization, executed in the human brain during the neural activity. They carry a number of names (schemata, scripts, frames, planes) depending on the theory used for the description of the phenomenon. During activities associated with communication, these structures, in turn, become the basis for the conventions called genres that concern the form and content of information provided as a text. Genres, as conventions known and used by both senders and recipients of messages, facilitate conversions such as information-knowledge-information (creativity) and knowledge-information-knowledge (communication).

Originality/value: The paper organizes knowledge concerning the processes of knowledge organization, combining a number of well-known neuroscience, psychology and sociology theories, which facilitates the appropriate localization of knowledge organization processes and tools they employ, i.e. knowledge organization systems.

\section{Keywords}

Geneploration. Genres. Knowledge organization. Knowledge organization systems. Mental schemata.

Dr hab. MAREK NAHOTKO jest adiunktem w Instytucie Informacji Naukowej i Bibliotekoznawstwa Uniwersytetu Jagiellońskiego, specjalizuje się w zagadnieniach metadanych dokumentów elektronicznych oraz wykorzystania Internetu w komunikacji naukowej i działalności informacyjnej. Jest autorem ksiażek Komunikacja naukowa w środowisku cyfrowym (Warszawa, 2010), Naukowe czasopisma elektroniczne (Warszawa, 2007), Opis dokumentów elektronicznych. Teoretyczny model i możliwości jego aplikacji (Kraków 2006), Metadane: sposób na uporządkowanie Internetu. (Kraków, 2004) oraz licznych artykutów publikowanych m.in. na łamach Przegladu Bibliotecznego, Zagadnień Informacji Naukowej oraz Biuletynu EBIB.

Kontaktzautorem: marek.nahotko@uj.edu.pl

Instytut Informacji Naukowej i Bibliotekoznawstwa

Uniwersytet Jagielloński

ul. prof. St. Łojasiewicza 4

30-348 Kraków

(pok. 3.378) 